\title{
An analysis of conflict situations within the leadership and various structures of the Dutch Reformed Church in Africa, Orange Free State
}

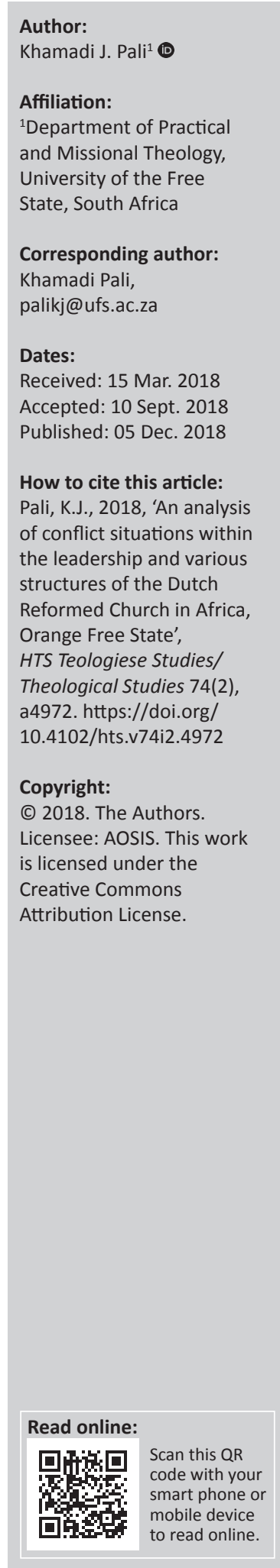

Conflict is inevitable within congregations and can contribute to their growth or decline, depending on how the leadership in a congregation handles a conflict. The Dutch Reformed Church in Africa, Orange Free State (DRCA OFS) has, for over a decade, experienced growing internal conflicts within its leadership in the various structures of the church. Some of these conflicts have culminated in physical violence and litigations. This article aims to analyse the emerging conflict situations within the leadership in the various structures of the DRCA OFS. The leading research question is: What are the dynamics of conflict situations of the leadership in the various structures of the DRCA OFS?

\section{Introduction}

In his book entitled Authority, Leadership and Conflict in the Church, Avis (1992:120) states that the manager's role in a conflict is to contain it, mediate and reconcile, whereas the leader's role is to harness conflict to serve the overall mission of the institution. As conflict is inevitable among human beings, it must not be allowed to exhaust its participants and paralyse the institution; it must be channelled away from infighting towards confronting the challenges emerging from the environment. In light of the above, it seems that there are various ways in which a leader and a manager respond to conflict. The manager contains conflict and endeavours to manage it, whereas the leader uses conflict as an opportunity to achieve the common mission of the institution. In relation to congregations, how does leadership respond to conflict in congregations? Does the leadership contain conflict like managers do, or harness it to facilitate transformation, as leadership should? Avis also warns that we must never allow conflict to destroy the institutions, but that we can use conflict to confront challenges facing the institutions. In congregations, the leadership often allows conflicts to grow to such an extent that congregations experience a division and slow death, instead of using conflict as an opportunity to transform the congregation.

This article intends to determine how the leadership in the Dutch Reformed Church in Africa, Orange Free State (DRCA OFS) ${ }^{1}$ responds to conflict situations in the various structures of the church. By leadership, the author refers to ministers, elders and deacons, as they are mostly involved in the leadership of the congregations, presbyteries and the synod. Various structures of the church refer to the congregation, presbytery and synod. The focus is on various structures of the church because most of the conflicts originate in the congregation and spill over to the other structures of the church. Some of the conflict situations are so complex that an observer or outsider finds it difficult to understand their origin; these conflicts do affect the relationship between, and the functioning of, various structures of the church.

It would be interesting to find out whether the leadership in the DRCA OFS uses conflict situations within its various structures to destroy or as an opportunity to transform. Conflicts discussed here are not just once-off discrete events but underwent a process that, in time, manifested into serious incompatibility, disagreements and dissonance among members and various structures of the church (Rahim 2001:18). As far as conflicts in the DRCA OFS are concerned, they evolve from bottled tension and hostile relations which occurred over decades. Now the bottled tension and suppressed hostile relations are expressed in the form of furious words and aggressive actions, hence now one can say the DRCA OFS is experiencing an increase in conflicts within its various structures (DRCA OFS 2007:9; 2011:25, 2015:20-23). These conflicts involve leadership,

1.It is also known in Afrikaans as Nederduitse Gereformeerde Kerk in Afrika Oranje Vrystaat (NGKA OVS). However, in this article, I will use the English abbreviated form DRCA OFS. 
congregation members and various structures of the church. This article focuses on leadership engagement of these conflict situations in various structures of the church. These conflicts emerge from internal and external factors that affect the DRCA OFS. The increment and the seriousness of these conflicts have become a growing concern of the moderamen about the situation and the integrity of the DRCA OFS (DRCA OFS 2015:32, 33).

In summary, this article chiefly aims to analyse the emerging conflicts within the leadership and various structures of the DRCA OFS. The objectives of the study are twofold: to identify the sources of the leadership conflicts within the various structures of the DRCA OFS and to describe their impact on the ministry of the DRCA OFS. The leading research question is: What are the dynamics of conflict situations within the leadership in the various structures of the DRCA OFS? This article, despite the use of scholarly literature, will use church documents, author's observation and empirical ${ }^{2}$ data from a joint $\mathrm{PhD}^{3}$ of Pali (2016) as basic sources for its discussion of conflicts in the DRCA OFS.

\section{Brief narrative of the Dutch Reformed Church in Africa, Orange Free State}

The DRCA OFS is one of the Dutch Reformed family of churches whose membership and leadership are predominantly black Africans. It is a product of the mission work of the Dutch Reformed Church in the Free State (DRC FS), and was established in 1910 for black Africans. In its early years it was a dynamic and thriving church whose membership and ministry grew because of the blessings of God. It used both white missionaries from the $\mathrm{DRC}^{4}$ and members of the DRCA such as ministers and catechists to do the mission of God in South Africa (Odendaal 1956:63). From 1910 to pre-1994, the DRCA grew from one to eight regional synods in the Republic of South Africa (Crafford 1982:149, 158, 173, 245, 564).

In 1994, all the regional synods of the DRCA initially resolved to unite with the Dutch Reformed Mission Church ${ }^{5}$ to form a new church known as the Uniting Reformed Church in Southern Africa (URCSA) ${ }^{6}$ (VGKSA 1994:282-287). However, the DRCA OFS and the DRCA Phororo ${ }^{7}$ regional synods later withdrew from a unification process to form URCSA (DRCA OFS 1999:6). This withdrawal resulted in constant 2.To know more about the details of the research methodology and this empirical
data, consult the joint PhD of Pali (2016:39-55, 79-154).

3.This joint PhD project was submitted in 2016 to Vrije Universiteit, Amsterdam and the University of the Free State, Bloemfontein in 2016. The title was 'Leadership and Transformation in the African Church: A Practical Theological Study of One Denomination'.

4.It is a church for the Afrikaner community in South Africa.

5.It was a church established by the DRC for people of colour in South Africa.

6.It is also known in Afrikaans as Verenigende Gereformeerde Kerk in Suider Afrika (VGKSA).

7.DRCA Phororo refers to DRCA congregations in the Northern Cape and North West provinces. litigation between the two regional synods of the DRCA and the URCSA over the property and recognition of the status of the DRCA (NGKA, s.a.; DRCA OFS 1995:9, 10, 11; 2007:8, $11 ; 2008: 3,8 ; 2011: 29)$. In 1998, the DRCA won the case regarding the conflict over recognition of the DRCA's status (NGKA s.a.). The case regarding the conflict over property was resolved in 2015 through a settlement and the arbitration of the DRC, much to the dissatisfaction of the majority of the DRCA congregations (DRCA OFS 2015:25-31).

In general, the withdrawal from a unification process to form URCSA caused the DRCA to suffer the loss of most of its ministers, congregation members and buildings, with the result that the two regional synods of the DRCA suffered a shortage of ministers which led to the need for interim ministers ${ }^{8}$ in more than one congregation. To counteract the shortage of ministers, the two regional synods of the DRCA resolved to train evangelists for two years to be promoted to ministers (DRCA OFS 1999:25, 26). This had mixed consequences. For some years, the ministers were relieved of the burden whereas, on the contrary, the majority of the evangelists and ministers were old and of retirement age. Hence, from 2011 to 2015, the number of ministers in the DRCA OFS in particular was drastically reduced from 60 to 40 because of death, retirement and resignation (DRCA OFS 2015:48). In addition, in 2015, more than half of the congregations had no ministers and had to be served by interim ministers, with the result that ministers were overburdened with ministerial duties and could not fulfil all their ministerial duties in their own congregations. Hence, some ministers became drained and exhausted because of their many responsibilities in the ministry (DRCA OFS 2015:49; Pali 2016:133, 134). Consequently, the ministers' exhaustion and inability to fulfil their ministerial duties in their own congregations or interim congregations gave rise to some tense relations and looming conflict in most of the congregations of the DRCA OFS (Pali 2016:103, 120).

To demonstrate, Pali's (2016:103, 120, 134, 146) empirical data which were collected in the DRCA OFS congregations before the DRCA OFS synod 2015 indicated the following: the quantitative data point to a growing exhaustion among ministers because of their many ministerial duties. The qualitative interviews point to an already growing tension in the relationship and looming conflicts within the congregations of the DRCA OFS. The moderamen of the DRCA OFS (2015:20-23) raised a concern over growing conflicts and that if not resolved they will affect the integrity and the ministry of the DRCA OFS.

This increasing tension in relationships and the looming conflict situations ultimately gave rise to conflicts within the congregations of the DRCA OFS. This was confirmed by the report of the moderamen of the DRCAOFS synod (2015:20-24, 39-43), which indicated that over half of the presbyteries complained on several occasions about the unresolved 8.Afrikaans-related concept is konsulent. An interim minister is a minister who temporarily helps in ministering to a congregation that does not have its full-time minister. 
conflicts in the congregations and among ministers. In my observation, from the DRCA OFS synod 2007 to the present, the DRCA OFS has experienced increasing conflicts ranging from disagreements and verbal insults to physical violence and litigation. Again, if one uses the progression scale on conflicts by Pondy (1967:302, 303), the conflicts in the DRCA OFS are heading towards a stage wherein there is no communication or co-operation among the various structures of the church, there is frustration and passive aggression over suspense of the activities of the various structures of the church and there is prevailing of fear for worse. The consequences, when at this stage, are that if there is no effective leadership to intervene and made appropriate decisions, the future relationship among those in the various structures of the church might be worse and a schism may occur. Amid these conflicts, the moderamen of the DRCA OFS $(2015: 32,35)$ raised the following issues of concern. The conflicts point to the lack and loss of divine love (Jn 13:35; Rv 2:2-5) within the leadership and members of the DRCA OFS. The conflicts among the leadership and members in the various structures of the DRCA OFS show the loss of integrity, authenticity and relevance of the DRCA OFS. If this is the situation, how will the DRCA OFS proclaim the good news to the world? How will it contribute to social renewal if it is not renewed? How will it contribute to compassionate justice if it cannot practise it within its own ranks? The current conflict situation in the congregations of the DRCA OFS prevents it both from effectively partaking in social reconstruction and renewal and from giving a critical account of the truth claims they should enact in practice.

\section{Definition, dimensions and significance of conflict}

The study of conflict in organisations, including congregations, is a growing and relatively recent field of study in the academic world (Berkovitch, Kremenyuk \& Zartman 2009:1; Kurtz 1982:111). To define it, conflict is complex and depends on context. Wilmot and Hocker (2011:911) define conflict as an expressed struggle between at least two interdependent parties who perceive incompatible goals, compete over scarce resources and resist interference from others in achieving their goals. According to Miller (2013:11), conflict is a lack of agreement over opposing issues or principles. According to Rukuni (2013:1), 'a conflict is a relationship in which two or more parties perceive that they have incompatible goals or means of achieving those goals'. In my understanding and observation of the situation in the congregations of the DRCA OFS, conflict is a verbal, physical, emotional and intellectual clash of ideas, emotions, goals and individuals over a specific goal, use of resources and transgressed ecclesiological procedure.

Mayer (2010:2) argues that conflict occurs at various dimensions in relation to human being: it may occur on a cognitive dimension whereby conflict is perceived as incompatibility of one's own needs, wants, interests and values with the other. Another dimension of conflict is the emotional dimension, whereby conflict is a reaction to a situation of crisis, instability or chaos which often gives rise to emotions of fear, anger, sadness, bitterness and hopelessness. Oppenshaw (2017:116) warns us that people's emotional state can trigger conflict because emotions can cloud logic and one's sense of decision-making. The last one is a behavioural dimension, which involves actions we take to express our emotions and articulate our perceptions. Usually our actions are the ones that ultimately reveal our inner intention, whether it is of expressing conflict or just aiming at getting one's needs met.

It is essential to study conflict within organisations, including congregations, to avoid repeating the damaging patterns in our organisations and congregations (Wilmot \& Hocker 2011:9). Conflict is an inevitable, inescapable and indispensable feature of people's lives (Avis 1992:120; Page 2008:286; Rukuni 2013:11). Conflict in leadership and congregations is real and part of everyday life of congregational ministry. For a long time, leadership in congregations has not dealt effectively with conflicts (Kurtz 1982:111). Consequently, according to Miller (2013:1), one of the main challenges facing churches is how to handle conflict in a biblical manner, and to sustain the spiritual maturity and growth of the church. Miller also argues that the manner in which congregations manage conflict situations may have a negative or positive impact on the ministry of congregations.

\section{Various perceptions of conflict}

People experience and perceive conflict in various ways. Ideally, one should have a balanced view of conflict. Hellriegel, Slocum and Woodman (1998:364-365) understand a balanced view of conflict as being sensitive to the consequences of conflict that may have either negative or positive outcomes. Potential consequences of conflict situations depend on how we handle conflict situations. According to Oppenshaw (2017:100), our response to conflict is a reflection of our limitations and ability to effectively use our potential resourcefulness and abundance we have to resolve conflict. Furthermore, our attitude during conflict determines whether consequences will be productive or destructive for the organisation or congregation (Page 2008:290). If the consequences of conflict situations are destructive, the relationship suffers. If the consequences of conflict situations are constructive, it may bind two parties together in a relationship. What entails a positive or negative view of conflict?

\section{Positive view of conflict}

The above discussion indicates that the consequence of conflict situations depends on our attitude and how we respond and handle it. To reap positive results from conflict, Christians should acknowledge that they have been forewarned about their sinful nature (1 Cor 3:3-4), which often promotes conflict situations. Hence, scripture cautions Christians about potential conflict in a ministry which can be in the form of violence (Mt 10:34-36), sorrows and trials (Jn 16:33; 1 Pt 4:12), or over limited resources (Gn 12:12-31), 
misunderstanding because of poor communication (Jos 22:12-34), differences in opinions (Ac 15:39) and gifts and callings (1 Cor 12:12-31). A positive view of conflict is the result of the ability to effectively manage conflict and use it as an opportunity to transform the situation. Not every leader has the potential to harness conflict situations for a deep change. Howell (2003:298) argues that one of the crucial points in choosing a good leader is how she or he handles conflict situations.

Page (2008:288) states that a properly managed conflict situation makes us grow stronger and teaches us to manage conflict well. Page (2008:291) also relates that the presence of conflict in a congregation is a warning that things are not working well and that change is needed. In such moments of a need for change, real leadership is manifested to provide creative solutions to a conflict. In addition, Page (2008:291) states that the presence of conflict creates an opportunity to assess the real character of believers when under pressure, or who we are as both individuals and a community (Oppenshaw 2017:100). This may elicit a hidden agenda that reveals core beliefs and values. The presence of conflict in a congregation creates an opportunity for a congregation to open up to its environment, to draw in new resources to replace those consumed by internal conflicts (Avis 1992:120). Lastly, conflict in a congregation can promote authenticity by empowering the community of faith to recognise diversity in ministry rather than emphasising an artificial homogeneous group (Rediger 1997:47).

Amid these growing conflicting situations in the DRCA OFS, one wonders whether leadership learns a positive lesson from most of the conflicts that occur in the various structures of the church. Objectively speaking, some conflict situations in the DRCA OFS demonstrate that the leadership has learnt a positive lesson and used the opportunity for improvement and change in the practice of ministry and ecclesiastical procedure in conflict management. For example, the amendments to the church order (DRCA OFS 2007:21; 2008:10; 2011:38, 39; 2015:56) and the readjustment of the synod borders (DRCA General Synod 2011:46, DRCA OFS 2007:10; 2011:26) are the result of positive lessons learnt from conflict situations. Another example of positive lessons learnt from conflict situations is the DRCA OFS's (2015:50, $53,63)$ resolution to adopt the mentoring system in an effort to counteract the increase in conflict situations, doing retreats for team- and relationship-building, and the necessity of practising reconciliation, unity and peace as believers in Christ.

However, for over a decade, the author observed that positive efforts by the DRCA OFS leadership to curb conflicts are overwhelmed by the negative consequences of conflicts. This is because of a growing tendency towards poor management of conflicts, which leads to more conflicts and divisions instead of spiritual growth and maturity in the congregations of the DRCA OFS. This will be discussed in more detail in the next section.

\section{Negative view of conflict}

According to Page (2008:287, 288), the vast majority of Christians view conflict as bad, unacceptable and sinful Christian behaviour. Some Christians understand conflict as coming only from the devil and those involved as having spiritual deficiency. According to Page (2008:292), those with a negative view of conflict display the following characteristics when involved in conflict situations: misunderstanding and anger; becoming long-term adversaries and chronic complainers; and resorting to manipulation, sabotage, insults and sulking to get what they selfishly want out of the conflict. They become so engaged with conflict that they are distracted from the real work, and overall productivity suffers as energy is wasted in conflict situations. Lastly, a harmful personal relationship emerges and they take sides with disputants.

Oppenshaw (2017:116) states that to some people situations of conflict tend to bring out the worst within them. This we realise when a negative perception of conflict leads to destructive and dangerous behaviour such as incivility, abuse and infighting, thus affecting the character and mission of the church (Rediger 1997:47). Hellriegel et al. (1998:364) argue that the negative energy derived from conflict diverts efforts from goal attainment, promotes the depletion of resources, affects the psychological well-being of members and causes depression, leads to resentment and anxiety, and ultimately affects performance.

From my observation and consultations of the DRCA OFS documents, there is an increase in the negative view and experience of conflict among the leadership and members in the congregations of the DRCA OFS. This is evident from the reactions of those in leadership and members. These range from a rebellious attitude, the use of obscene language and a refusal to co-operate with the structures of the church to physical violence and litigation. The following examples illustrate the negative perceptions and consequences of conflict situations in the DRCA OFS. The incidents will be analysed in relation to cognitive, emotional and behavioural dimensions of conflict. Firstly, at the DRCA OFS synod (2015:38) and Extraordinary synod $2017^{9}$ meetings, the author observed a display of anger and frustration, the use of obscene language and a rebellious attitude by some ministers and representatives of congregations when the leadership refused to allow the appointment of the temporal Independent Electoral Commission (IEC) for the election of the moderamen, and again in 2017, when the leadership refused to allow additional items on the agenda for the Extraordinary synod 2017. From the above scenarios, one can analyse that in the cognitive dimension of conflict there was incompatibility of opinions between the leadership and the representatives at both synodical meetings on appointment of the temporal IEC and allowing additional items on the agenda. This triggered emotions of anger, sadness towards leadership and fear of manipulation of election results and the defeat of the ultimate

9.Note that during this DRCA OFS Extraordinary synod 2017 the situation became worse to such an extent that the synod meeting was adjourned and many DRCA OFS synodical activities were suspended until further notice. 
purpose of the Extraordinary synod 2017. Consequently, some of the representatives in the DRCA OFS synod 2015 acted by threatening with intention to interdict the synod, whereas others developed mistrust of the elected leadership and started to mobilise against it. In the DRCA OFS and Extraordinary synod (2017), the consequences were swearing and shouting at leadership, and physical threats towards leadership and permanent adjournment of the DRCA OFS Extraordinary synod (2017).

Secondly, in the DRCA OFS 2011 synodical meeting, the author observed how conflict could turn ministers of the Word into permanent enemies. One of the young ministers was called by a specific congregation in one of the presbyteries of the DRCA OFS. Unfortunately, this young minister had a serious quarrel with his church council and the presbytery resolved that the young minister must be released from the duties of his congregation. However, in the process of preparing for the release of this young minister, the chairperson of the presbytery personally threatened, forcefully removed and chased the young minister from the mansion without following the proper procedures of the church order. He delayed giving the young minister his demission letter on the pretext that the young minister must fulfil the conditions set by the presbytery commission. The mentor to this young minister tried to intervene in the matter, but the chairperson of the presbytery refused to co-operate with the mentor. This issue was discussed in the DRCA OFS (2011:36) synodical meeting, at which an intense exchange of words occurred between the mentor and the chairperson of the presbytery. In relation to the cognitive dimension of conflict, conflict could be because of lack of understanding from the chairperson of the presbytery on the protocol to be followed for administering the demission letter when releasing a minister from a congregation. Again, cognitively one can perceive the conflict as lack of respect of integrity of the other and abuse of power by the chairperson of the presbytery. This practice aroused emotions of anger, bitterness and frustration from the young minister who felt weak and abused by this act of the chairperson of the presbytery. Consequently, the young minister acted by appealing to the DRCA OFS synod and seeking the assistance of his mentor. The end results of this conflict led to an action whereby the chairperson of the presbytery was reprimanded by the synod and ordered to give demission letter to the young minister. The young minister and his mentor later developed a hostile relationship with this chairperson of the presbytery who initially refused to give the demission letter to the young minister.

Thirdly, it appears that the refusal to co-operate with the higher structures of the DRCA OFS is a growing tendency in the congregations of the DRCA OFS (2015:24, 23, 32, 34, $41,51)$. The following examples suffice to demonstrate. Some ministers, without the proper protocol, tend to function as tentmakers and, when confronted with this, threaten to withdraw their ministerial services as some form of punishment to the church council or congregations and to sue the presbytery if it tries to intervene. The other incident is about a minister who was accused of sexual immorality and disruption of the synodical commission in 2013; when confronted, he refused to co-operate with the presbytery and to apologise for his wayward behaviour. The analysis of the above two incidents from the cognitive dimension of conflict is that they indicate that there are some ministers in the DRCA OFS who undermine or disregard the authority of the higher structures of the DRCA OFS. Emotionally, this triggers feelings of frustration and anger to those in leadership if they feel helpless to a situation. Unfortunately, the above incidents precipitated acts that demonstrated undermining of leadership authority within the DRCA OFS, whereby ministers who commit immoral acts are no longer disciplined.

Fourthly, and lastly, when in conflict, some of those in leadership and some members of congregations resort to violence in the form of disruption of worship services, obscene language, protest and physical threat (DRCA OFS 2008:4; 2015:33, 34, 49,54). This is also one of the growing conflict situations in the congregations of the DRCA OFS. The first incident of disrupting worship services happened in several congregations in various presbyteries (DRCA OFS 2015:32). These disruptions to worship services are the result of the conflict between leadership of the church council and congregation members (the youths) (DRCA OFS 2008:4). The second incident happened when the ministers and some representatives of congregations to the DRCA OFS synod disrupted the synodical commission by using obscene language, physical threat, clapping hands and making a noise (DRCA OFS 2015:38, 51). The third and last incident occurred when members of the church council and congregations were in conflict with the minister and physically removed him from the mansion or pulpit and threatened him with death should he return (DRCA OFS 2015:32). The above incidents, from the cognitive dimension of conflict, indicate that some congregation members and ministers have a perception that those in leadership no longer value and appreciate their followers. This is evident from an inability to listen to and respect the will of the members of the DRCA OFS by some in the leadership of the various structures of the DRCA OFS. Emotionally, the presence of some ministers in the leadership of the DRCA OFS in some instances triggers feelings of anger and frustration, hence some members and ministers resort now to actions of violence, obscene language and physical threats.

The above discussion adequately demonstrates that there are more negative and destructive experiences of conflict rather than positive and constructive consequences of conflict in the congregations of the DRCA OFS. As conflict situations are increasing, what kinds of conflicts do exist in the congregations of the DRCA OFS?

\section{Forms of conflict}

Various forms of conflict occur within organisations and congregations. Boahen (1987:26) and Hellriegel et al. (1998:366-371) mention the following. First, it will be a 
discussion of forms of conflict related to individuals or groups of people. Intrapersonal conflict within a person is caused by psychological and emotional pressures or unresolved competing needs, values or goals that may occur within an individual (Everist 2004:15). One example is a minister in one of the congregations of the DRCA OFS who mentioned that he is charismatic in his ministerial approach, and that he often experiences conflict between the reformed approach to ministry, as adhered to in the congregations of the DRCA OFS, and his charismatic approach.

Interpersonal conflict occurs between two or more people who perceive that their attitude, ideology, preferred goals or the use of scarce resources contradict each other's preferred needs. This appears to be a more common form of conflict in the congregations of the DRCA OFS. It occurs as conflict between a minister and his colleague or a minister and member(s) of the congregation, church council, presbytery or regional synod, or vice versa.

Intragroup conflict involves conflict among members within the same group; it is usually characterised by ideological differences or interpretation of policies by members of the same group. In the DRCA OFS, this may take the form of a conflict among members of the church council, congregation, presbytery or regional synod. One example is of a congregation that is divided into two factions: one supports the minister and the other a proponent (DRCA OFS 2007:8). Another example is when a congregation is divided into two sections: one supports the decision to shift to another newly formed synod, whereas the other supports the idea of remaining within the DRCA OFS synod (DRCA 2015:54).

In an intergroup conflict, two or more homogenous groups clash over either scarce resources or ideologies. In the DRCA OFS, an organisation in the congregations of the DRCA OFS clashed with one of the structures in the DRCA OFS, or different organisations within the same structures of the DRCA came into conflict with each other. For example, a women fellowship within the DRCA OFS was once accused by the DRCA OFS synod (2007:9) for transgressing the church order when they decided to make a distinct uniform for the ministers' wives without the approval of the synod. Another example is of a congregation that clashed with the DRCA OFS synod over a process to shift its membership from one synod to another (DRCA OFS 2007:13, 14). The last example is of a regional synod, such as the DRCA OFS, that refuses to accede to the request of the DRCA General Synod to meet with other DRC family churches, including the URCSA, to discuss unity, reconciliation and peace. The DRCA OFS refused that request in protest against the lost property to the URCSA which was not yet resolved (DRCA OFS 2007:9).

The following forms of conflict are directed towards intangible things like role, procedure or faith matters. Role conflict (Hellriegel et al. 1998:363, 364) occurs when a member and congregations complain about a minister's or a presbytery's refusal to serve a particular congregation within their jurisdiction (DRCA OFS 2015:23).
A procedural conflict involves people differing over which process to use for resolving a matter (Hellriegel et al. 1998:363, 364). In the DRCA OFS, this usually takes the form of an erroneous interpretation of the church order or disregarding the church order procedure to do some activities. For example, a presbytery that unlawfully allows the calling of a minister who is over the retirement age of 70 years in the DRCA OFS (DRCA OFS 2007:10, 26, 2015:24, 34); the establishment of a congregation without proper consultation of the presbytery (DRCA OFS 2007:10); ordaining, dismissing and suspending a minister from his or her duties (DRCA OFS 2007:12, 13, 27, 28; 2008:4; DRCA 2015:22, 23); and calling a church council, presbytery and regional synod meeting without the proper protocol (DRCA OFS 2015:24, 34).

The above-mentioned forms of conflict are intrinsically linked and it is often not easy to classify them, unless one understands the origin, contents and context of these conflict situations. One form of conflict tends to lead to another, if it is not adequately addressed from the onset.

\section{Sources of conflict}

According to Miller (2013:76-79), conflicts in churches occur for various reasons, namely the sinful nature of believers (G1 5:19-20); believers living in a spiritually fallen world (Gl 3:22); the pursuit and influence of the evil one (1 Pt 5:6-9; Eph 4:27); lost people among the church membership (Mt 13:24-30,36-43); differences among people in the church; and Christians yielding to the control of their sinful nature instead of that of the Holy Spirit (Eph 2:1-3). Furthermore, sources of conflict discussed in the next section are mostly caused by internal factors, while external factors play a very limited role in the conflict situations in the DRCA OFS.

\section{Leadership in the congregations}

The general impression from Pali (2016) and the study of DRCA OFS documents relating to conflicts is that leadership is the main culprit for most of the conflict situations in the various structures of the DRCA OFS. Leadership refers mainly to the minister, elders and deacons who together form the church council of a congregation. Most of the conflict situations can be avoided and prevented. However, because of lack of conflict management skills, some conflicts escalate into serious ones with dire consequences.

\section{Use of power and authority}

Gibbs (2005:31) argues that leadership is respected when authority is earned and power shared among those involved in leadership. Power in leadership is the ability to compel others to do something, whether legitimate or not. Authority is the ability to persuade, command or exact obedience (Avis 1992:25; Rausch 1989:38). Power and authority in leadership can help suppress or promote conflict (Avis 1992:119). How are power and authority used in the DRCA OFS?

One issue I observed as a weakness in the DRCA OFS is that one person tends to occupy more than one position in the 
various structures of the church. This has the potential to breed corruption and misuse of power by some ministers. For example, I remember, when I was still in the youth movement, that many viewed our minister as autocratic and influential. He occupied important positions in various church structures. In the presbytery, he used to appoint and fire the leadership of the presbytery as he wished. If the aggrieved appealed to the higher structures of the synod, he would, as a very influential member of the moderamen, easily convince the moderamen to refer the matter, knowing very well that when the matter is referred to the presbytery, he would adequately deal with those who complained about him. He would reprimand or fire them from their positions in the presbytery. This was a common practice among some ministers, especially those who were well known and influential in the various structures of the church. Some of these ministers would even boast about being well connected within the various structures of the church. As a result, nobody can report them without them knowing and accessing the information.

\section{Church order and management}

According to Pali (2016:206), culture, history and the theology of denominational leadership influence church management. The adopted and institutionalised church order and management have an enormous impact on the leadership practice in the ministry of congregations. If not understood, it can lead to numerous legal prosecutions and more conflicts in the church. To avoid conflicts, leadership training should engage in the study of denominational polity and congregational by-laws, to promote spiritual discipline and the practice of effective leadership.

From an objective point of view, the church order of the DRCA OFS is clear on most of the procedures to be followed when performing activities within any structure of the church. For example, the DRCA OFS Church Order (2003:Articles 6, 7, 8, 9, 10) is clear concerning the ordination of the proponent, as well as the calling, suspension and procedure for retirement of the minister. The DRCA OFS Church Order (2003:Chapter 6) is also clear on how to deal with grievances between individuals, the appeal procedure as well as the process of calling meetings on various levels of the church structure. The DRCA OFS Church Order (2003:Article 51) clearly states that the stipulations in the church order must be applied in the spirit of love, reconciliation and justice and that the perpetrators must humble themselves to obey the decision of the disciplinary hearing if found guilty of transgressing the church order.

On several occasions, I observed that, in most of the congregations of the DRCA OFS, the church order is applied legalistically and in favour of ministers more than anyone else in the congregations of the DRCA OFS (DRCA OFS 2015:32, 49). I also observed that most of the church council members do not have the church order document, even though anybody can purchase it from the head office of the DRCA OFS. As a result, most of the church council members in the congregations of the DRCA OFS do not know the contents of the church order and depend on the minister for interpreting and applying the church order. Consequently, some ministers often misinterpret the church order for their own purposes and use it to threaten others. Thus, when the minister is at fault, the church council does not know how to react to the situation.

\section{Theological identity}

Churches, especially reformed churches, should have their foundational identity embedded in the Triune God. Although theology is derived from the understanding of the Triune God, the denomination's interpretation of the activities of the Triune God is perceived differently and interpreted subjectively, hence the charismatic, reformed and African theologies. In the context of the DRCA, reformed theology is the predominant form of theology practised (DRCA OFS, Church Order 2003:Article 59). According to Smit (2009:424), reformed theology is not only about personal piety which confines itself to the intimate relationship with the Triune God, but it is also about public life which involves whole life, political and social order, history and the world. Influenced by the reformed theology of the 16th-century reformation, reformed churches are facing the challenge of using confessional formulas as identity and instrument to exclude others, thus promoting division (Bosch 2000:240). Consequently, reformed churches face the challenge of a lack of unity, reconciliation and compassionate justice.

The above challenges of the reformed churches are relevant in the DRCA OFS. During the apartheid era and even in present-day democratic South Africa, the DRCA OFS and its relation with the state was, and still is, mostly one of mute criticism. Its current social involvement can be attributed to a level where only immediate needs, such as food and clothing, are addressed (Pali 2016:61, 111). To the DRCA OFS, the problem of accepting the Belhar Confession as a new creed formula was, and still is, a hindrance in the process of unity with other DRC family churches. From the empirical data of Pali 2016, it was discovered that most of the ministers in the DRCA OFS are not prepared to subscribe to the Belhar Confession. ${ }^{10}$ This is not good news, pending negotiations for unity of the DRC family of churches.

\section{Fear of change}

Because of globalisation, postmodernism and technological development, change occurs at a faster rate than previously. Humanity, churches and organisations find it difficult to cope with change. The time is long gone for churches to enforce the practice of the same approach to worship service. It is not Biblical for congregations to be stagnant and inwardly focused. Congregations need to be dynamic and respond continuously to the discernment of the spirit in congregations. However, according to Rendle (2000:9), congregations fear too much change because things may get out of control, and they fear hardly any change because it will make the congregation 10.See Minister's survey (MS) (Pali 2016, empirical data). 
stagnant. Rendle (2000:173) also argues that change in a congregation should involve and begin with leadership for a smooth transition and implementation of the process of change. For example, most of the congregations need to transform their mission, identity and vision to improve their ministry. However, to implement the above-needed change, leadership that has experienced that needed change is essential (Hendriks 2004:197). Fear of change manifests in the DRCA's resistance to introducing musical instruments, singing of choruses and dancing to the tune of the hymn. This is evident from the DRCA OFS synod 2015 (Addendum: Report of the Decisions of the DRCA General Synod 2015). A synod resolved to compel ministers and church council members to sign a pledge to adhere to the church order, tradition and liturgical practice of the DRCA.

\section{Introduction of new programmes in the congregations}

Congregations are meant to be dynamic and continuously transforming if they are to adapt to a continuously changing context. There is a need for new programmes that promote the spiritual maturity of believers and encourage creative ways of doing ministry in the current context. Unfortunately, the introduction of new programmes into the ministry is often met with resistance from both or either the members or leadership in the congregations.

As mentioned earlier, the use of musical instruments, singing contemporary choruses and dancing to the rhythm of the hymn are prohibited in the congregations of the DRCA OFS. These practices are considered foreign to the tradition of the DRCA OFS and taint its identity and ministry. Hence, in DRCA OFS synod 2015, a resolution was adopted to compel ministers and church council members to sign a pledge to maintain the traditional practices of the DRCA OFS. In my observation, this resistance to accommodate new and creative practices of ministry in the congregations of the DRCA OFS has caused conflict in the past and is a sign of the leadership's failure to creatively adapt to new approaches to ministry. The example of a minister introducing mass prayer in the worship service demonstrates the seriousness of resisting new programmes in the congregations of the DRCA OFS (DRCA OFS 2015:21). In the DRCA OFS, a person appointed from the church council or from members of the congregation usually conducts prayer after the sermon. However, in this incident, instead of requesting one person to pray, a minister introduced mass prayer by all congregation members. Some of the members of the congregation and leadership of the presbytery reacted in such a way that the minister was dismissed from the congregation on the pretext that he adopted the foreign practices of other churches and transgressed the traditional practices of the DRCA OFS. Later, the DRCA OFS synod 2015 passed a resolution that all the ministers and church council members must sign a pledge promising that they will adhere to the tradition and identity of the DRCA OFS and will never deviate from the liturgical process of the DRCA OFS during the worship service.

\section{Exposed sin}

According to Kihiko (2004:11), it is not easy for a leader to own up to a sin. Consequently, if a leader is not ready to confess his sin, those who know about this sin are likely to expose the minister. Some of the most common sins committed by the ministers are adultery, financial fraud or alcohol misuse. During my youth, it was common in the congregations in which I was involved to hear about a minister being involved in extramarital affairs with one of the women in the congregation. During our youth conference, it was not unusual to hear about some of the ministers being involved in sexual relationships with some of the young ladies in the youth movement. This ill-discipline by some senior ministers concerning sexual matters influenced and led to sexual laxity by some young ministers and student ministers whereby some of the young ministers married ladies whom they did not intend to marry, to avoid being exposed and disciplined. On the issue of misuse of church funds, it often happened in some congregations where ministers are still considered more educated compared with congregation members. Because of lack of administrative skills, the minister is compelled to help with administration work. This may sometimes even include financial administration. Some ministers were thus tempted to misuse the finances of their congregations, or failed to account for the finances used, resulting in their being accused of misusing the funds. An example of the misuse of alcohol is that some ministers in the congregations of the DRCA OFS were well known as drunkards; they even drank in public and sometimes even attended various assemblies of the DRCA OFS reeking of alcohol. Nothing was done to discipline them. Some of them passed away because of alcohol-related illnesses.

\section{The way in which a leader caught in sin is handled}

Kihiko (2004:12) argues that, often in the congregations, when a member has committed a sin it is announced publicly in the church and the necessary disciplinary procedures are followed. However, when a minister has committed a sin, the church leadership remains silent about it. Nothing is done to discipline the ministers until congregation members spread rumours about it. A recent growing trend is to treat ministers differently to congregation members when caught in sin. It has also become evident that ministers refuse to be disciplined when caught in sin. For example, in 2015, some financial mismanagement was reported at the DRCA OFS head office (Secretary of the DRCA OFS synod 2015). In subsequent meetings of the DRCA OFS it was reported that the church administrator confessed about the missing funds at the DRCA OFS head office. The matter was meant to be reported to the police and be subjected to church discipline. The church administrator was charged (Van Rooyen 2017). When it came to disciplining the church administrator, the presbytery in which this church administrator is involved and some ministers in the DRCA OFS stalled the process of disciplining the minister. They claimed that he confessed and that he must be forgiven. From 2015 to the present, in one of 
the congregations in the DRCA OFS, a minister was accused of sending pornographic material to a woman in his congregation; the presbytery took a long time to discipline the minister. Eventually, the minister apologised and was forgiven by the presbytery, whereas the husband of the woman who received pornographic material and some congregation members pursued the matter further, insisting that the minister be suspended. All was in vain (Xaba 2016; Mahase 2018).

\section{External sources of conflict}

The above sources of conflict are mainly from internal factors. Some external factors contribute to conflict situations in the congregations of the DRCA OFS; for example, the issue of the URCSA. This started as the internal matter of the DRCA OFS. When the URCSA was formed, the litigation over the recognition of the status and property caused the source of conflict within the congregations of the DRCA OFS to become an external factor. The other example is of the South African National Civic Organisation which requested the DRCA OFS to give land for a graveyard and for the establishment of an informal settlement (DRCA OFS 1995:10). The church rejected this request. The land was illegally occupied and an informal settlement was built on that land.

\section{Conflict resolutions}

To Christians, the Bible is the primary source of Christian literature concerning conflict resolution (Miller 2013:30). Kurtz (1982:111) relates that, for a long time, congregational leadership has failed to use Biblical principles in dealing with conflict.

In addition to the Bible, the resolution of a conflict requires administrative skills and a considerable knowledge of organisational strategies, neither of which were given high priority. In dealing effectively with conflict in an organisation, one has to move from conflict management and conflict resolution to conflict transformation. According to Hellriegel et al. (1998:363), conflict management involves the use of a diagnostic process, interpersonal styles, negotiating strategies and other interventions designed to avoid unnecessary conflict. In addition, Oppenshaw (2017:106) understands conflict management as emphasising an idea of resolution of conflict not by getting rid of it, but by controlling its destructive consequences and components. Berkovitch et al. (2009:1) describe conflict resolution as creative ideas, theories and methods that are used to improve our understanding of conflict and the collective practice of reducing conflict to promote harmony and peace. According to Oppenshaw (2017:104), conflict resolution must not be separated from a situation and contextual issues. For example, in the context of the DRCA OFS culture, history, legacy of white imperialism and human weakness are some of the factors that need attention to resolve conflict issues within the congregations of the DRCA OFS. Furthermore, conflict resolution must engage issues and problems, not humiliate the person involved (Tidwell 2001:2). Full conflict resolution must address the cognitive, emotional and behavioural dimensions of conflict (Mayer 2010:108). However, most important is that conflict resolution must not only be preventative but reconciliatory as well (Oppenshaw 2017:105). In the DRCA OFS, the leadership did try its best to reconcile some parties in conflict, but often it has not succeeded and most conflict resolutions target persons, not problems (DRCA OFS 2011:36, 2015:40).

Conflict transformation can be described as changing the conditions and relations of parties that created and were involved in conflict so that these parties can become agents of transformation in other conflict situations (Boahen 1997:20). According to Oppenshaw (2017:107), conflict transformation extends beyond peace commitment towards respect of the other, transforming the culture and context of the parties to incorporate others into a peaceful process. In light of the above, the DRCA OFS is still struggling with conflict management and resolution; it has not yet moved towards conflict transformation.

\section{Process of conflict resolution}

There are various ways in which the congregations in the DRCA OFS resolve their conflicts. The first one is when the case is appealed to a higher structure or referred back to the lower structure of the DRCA OFS. For example, a conflict between the minister and the proponent over the leadership of the congregation (DRCA OFS 2007:8); youths complaining to the synod about the wrong protocol in the calling of a minister or the ill-disciplined minister (DRCA OFS 2007:13); or a minister released without consultation with the presbytery. The above cases were appealed to the higher church structure and were all referred back to the lower structure to resolve them.

The second one is by advice (DRCA 2007:9, 12). Often, when two individuals are in conflict, they approach the relevant church structure to intervene and the unhappy party approaches the higher church structure for appeal. The response: when the higher church structure realises that the procedure is correct, it can simply advise the appellant that she or he must accept the decision. Sometimes a word of advice is given, with a strong connotation of reprimand against the practice of wrongful action or provision of advisory information for future practices.

The third one is by warning others to deter them from dangers consequent to their actions (DRCA OFS 2007:9, 13). For example, some congregations and members asked the DRCA OFS about joining the new, unlawfully established DRCA synod. The DRCAOFS synod warned them against the consequences of joining the unlawfully established DRCA synod.

The fourth one is by public apology against the wrong action done (DRCA OFS 2007:9). An example is when the women fellowship designed a new uniform for the ministers' wives without the permission of the synod, and the leadership of the DRCA women fellowship apologised for such ignorance. 
The fifth one is by negotiations (DRCA OFS 2008:7). The example is when DRCA OFS and DRCA Phororo synods meet to discuss the issue of borders between the two synods.

The sixth one is by mediation between rival parties in the lower structures of the church (DRCA OFS 2015:20, 34). An example could be when a DRCA OFS moderamen, together with other commissions of the synod, intervened in one of the presbyteries where ministers were in conflict with each other to such an extent that congregations were divided, relationships tense among those in the presbytery and ministers neither talking to nor respecting each other.

The seventh one is by the removal of both rival parties from a congregation. To bring about a resolution to a conflict between a chairperson of the presbytery and a proponent, both of them were removed from the congregation involved and an interim minister was appointed to lead the congregation to bring about peace and calm to an affected congregation (DRCA OFS 2007:8).

The eighth one is by intervention with the purpose of reconciling the rival parties (DRCA OFS 2015:40). Senior ministers were sent to engage with a young minister who was in conflict with his church council to restore a cordial relationship and peace. Regrettably, this was not successful as the young minister did not co-operate and eventually he left the congregation for another one.

\section{Conclusion}

The aim of this article was to analyse the emerging conflicts within the leadership and various structures of the DRCA OFS. The DRCA OFS is experiencing conflict situations that range from simple disagreements on some procedures and roles to physical conflict and litigation. These conflicts mostly involve ministers, elders, deacons and members in various structures of the church. The source of these conflicts is mainly internal, and the main culprit is the leadership that misinterprets the church order, the misuse of power and authority, the resistance to introduce new programmes, and externally it is civic organisations and the relationship with the URCSA. The leadership in the congregations of the DRCA OFS is making an effort to resolve conflicts; they even use a biblical approach of seeking reconciliation, forgiveness and peace. The biblical approach failed. Hence, there seem to be increasing conflicts because of lack of conflict resolution and management skills. Consequently, the conflict situations in the DRCA OFS are slowly exhausting the members and the leadership and will ultimately paralyse the ministry in the DRCA OFS (2015:49). The current effort of the leadership of the DRCA OFS in conflict situations has failed to use conflict situations to engage the challenges of the DRCA OFS for the purpose of deep change. In fact, it appears that the leadership insists on maintaining the status quo, resisting change and letting things become stagnant.

In response to the research question, the dynamics of conflict situations in the DRCA OFS are such that the conflict situations in the congregations of the DRCA OFS are mainly because of internal factors of the ministry, compared with the external factors of the ministry. The conflicts range from simple disagreements over a specific role or procedure to physical violence and litigation.

In conclusion, the majority of the leadership in the congregations of the DRCA OFS do not know how to handle conflict in such a way as to promote the spiritual maturity and growth of the congregations. Instead, conflicts are slowly destroying and paralysing the church, exhausting the leadership and demoralising the members of the DRCA OFS.

\section{Acknowledgements Competing interests}

The author declares that he has no financial or personal relationships which may have inappropriately influenced him in writing this article.

\section{References}

Avis, P., 1992, Authority, leadership and conflict in the church, Mowbray Press, London.

Berkovitch, J. \& Jackson, R.D., 2009, Conflict resolution in the twenty- first-century: Principles, methods and approaches, University of Michigan Press, Ann Arbor, MI.

Berkovitch, J., Kremenyuk, V. \& Zartman, I.W., 2009, 'Introduction: The nature of conflict and conflict resolution', in J. Berkovitch, V. Kremenyuk \& I.W. Zartman (eds.), The Sage handbook of conflict resolution, pp. 1-11, Sage, London.

Boahen, A., 1987, African perspectives on colonialism, Johns Hopkins University Press, Baltimore, MD.

Bosch, D.J., 2000, Transforming mission, Orbis Books, New York.

Crafford, D., 1982, Aan God die dank, NG Kerk-boekhandel, Pretoria.

Dutch Reformed Church in Africa (DRCA), General Synod, 2011, Agenda of the DRCA general Synod, s.n., Bloemfontein.

Dutch Reformed Church in Africa Orange Free State (DRCA OFS), 1995, Agenda of the DRCA OFS Synod, s.n., Parys.

Dutch Reformed Church in Africa Orange Free State (DRCA OFS), 1999, Agenda of the DRCA OFS Synod, s.n., Thaba-Nchu.

Dutch Reformed Church in Africa Orange Free State (DRCA OFS), 2003, Church Order, s.n., Bloemfontein.

Dutch Reformed Church in Africa Orange Free State (DRCA OFS), 2007, Agenda of the DRCA OFS Synod, s.n., Tseseng, Qwaqwa.

Dutch Reformed Church in Africa Orange Free State (DRCA OFS), 2008, Agenda of the Synodical Commission of the DRCA OFS, s.n., Saaiplaas.

Dutch Reformed Church in Africa Orange Free State (DRCA OFS), 2011, Agenda of the DRCA OFS Synod, s.n., Kroonstad.

Dutch Reformed Church in Africa Orange Free State (DRCA OFS), 2015, Agenda of the DRCA OFS, s.n., Steynsrus.

Dutch Reformed Church in Africa Orange Free State (DRCA OFS), Extraordinary synod, 2017, Agenda of the DRCA Extraordinary Synod, s.n., Virginia.

Everist, N.C., 2004, Church conflict: From contention to collaboration, Abingdon Press, Nashville, TN.

Gibbs, E., 2005, Leadership next. Changing leader in a changing culture, Intervarsity Press, Leicester.

Hellriegel, D., Slocum, Jr., J.W. \& Woodman, R.W., 1998, Organisational behaviour, 8th edn., South-Western College Publishing, Cincinnati, OH.

Hendriks, H.J., 2004, Studying congregations in Africa, Paarl Print, Paarl.

Howell, Jr., D.N., 2003, Servants of the servant. A Biblical theology of leadership, Wipf and Stock Publishers, Eugene, OR.

Kihiko, M.K., 2004, Resolving church splits, King's Script Publishers, Nairobi.

Kurtz, A., 1982, 'The pastor as a manager of conflict in the church', Andrews University Seminary Studies 20(2), 111-126.

Mahase, M.S., 2018, Letter to the NGK Skakel-kommissie, 18 January.

Mayer, B., 2010, The dynamics of conflict resolution: A practitioner guide, John Wiley Sons, San Francisco, CA, viewed 07 September 2018, from http://orgwise.ca/sites/ osi.ocasi.org.stage/files/resources/The $\% 2$ Dynamics $\% 20$ of $\% 20$ Conflict $\% 20$ Resolution.pdf

Miller, M.D., 2013, A program of ministry to manage conflict: A doctor of ministry project, A doctoral degree submitted to the Temple Baptist Seminary, Madison, FL.

NG Kerk in Afrika (NGKA), s.a., viewed 28 January 2016, from www.ngka.co.za/ngka 
Odendaal, A.A., 1956, Litaba tsa Kereke ea Ned, Geref.N.G. Sendingpers, [s.I.].

Oppenshaw, D.L., 2017, Conflict resolution and reconciliation within congregations, PhD Thesis, University of Pretoria, Pretoria, viewed 27 November 2018, from http://hdl.handle.net/2263/63030

Page, D., 2008, Effective team leadership, Evangel, Nairobi.

Pali, K.J., 2016, 'Leadership and transformation in the African church: A practical theological study of one denomination', A joint D.Phil. thesis, University of the Free State, Bloemfontein \& Vrije Universiteit, Amsterdam.

Pondy, L.R., 1967, 'Organizational conflict: Models and conflict', Administrative Science Quarterly 12(2), 226-320, viewed 24 August 2018, from http://www.jstor. org/stable/2391553

Rahim, M.A., 2001, Managing conflict in organizations, Greenwood Publishing Company, Westport, CT, viewed 07 September 2018, http://www.untag-smd.ac.id/ files/Perpustakaan_Digital_1/CONFLICT\%20MANAGEMENT\%20Managing\%20 conflict $\% 20$ in $\% 20$ organizations.pdf

Rausch, T.P., 1989, Authority and leadership in the church: Past directions and future possibilities, Michael Glazier, Wilmington, DE.

Rediger, G.L., 1997, Clergy killers: Guidance for pastors and congregations under attack, Westminister John Knox Press, Louisville, KY.
Rendle, G.R., 2001, Leading change in the congregation: Spiritual and organisationa tools for leaders, Alban Institute Publications, Durham, NC.

Rukuni, O., 2013, Peace, leadership, conflict resolution and development, Lap Lambert Academic Publishing, Saarbrücken.

Secretary of the Dutch Reformed Church in Africa, Orange Free State Synod, 2015 A circular letter to all the congregations of the DRCA OFS, Bloemfontein, 05 November 2015.

Smit, D.J., 2009, 'Can we still be reformed? Questions from a South African perspective', in R. Vosloo (ed.), Essays on being reformed. Collected essays (3) Smit, D.J., pp. 423-440, Sun Press, Stellenbosch.

Van Rooyen, M., 2017, Reverend in court with 'combative guardian angel' by his side News 24, viewed 11 April 2017, from https://www.news24.com/SouthAfrica/ News/reverend-in-court-with-combative-guardian-angel-by-his-side-20170411

Verenigende Gereformeerde Kerk in Suider-Afrika, 1994, Handelinge van die stigting en eerste Algemene Sinode van die Verenigende Gereformeerde Kerk in Suider Afrika, s.n., Belhar.

Wilmot, W. \& Hocker, J., 2011, Interpersonal conflict, 8th edn., McGraw-Hill Publishers, New York.

Xaba, B.M., 2016, Letter to the DRCA Bloemfontein circuit, 30 January. 